\title{
Engaging with curriculum reform: insights from English history teachers' willingness to support curriculum change
}

Article

Accepted Version

Harris, R. and Graham, S. (2019) Engaging with curriculum reform: insights from English history teachers' willingness to support curriculum change. Journal of Curriculum Studies, 51 (1). pp. 43-61. ISSN 1366-5839 doi:

https://doi.org/10.1080/00220272.2018.1513570 Available at https://centaur.reading.ac.uk/78799/

It is advisable to refer to the publisher's version if you intend to cite from the work. See Guidance on citing.

To link to this article DOI: http://dx.doi.org/10.1080/00220272.2018.1513570

Publisher: Taylor \& Francis

All outputs in CentAUR are protected by Intellectual Property Rights law, including copyright law. Copyright and IPR is retained by the creators or other copyright holders. Terms and conditions for use of this material are defined in the End User Agreement.

www.reading.ac.uk/centaur 
Central Archive at the University of Reading

Reading's research outputs online 


\title{
Engaging with curriculum reform: insights from English history teachers' willingness to support curriculum change.
}

\author{
Richard Harris and Suzanne Graham
}

Institute of Reading, University of Reading, Reading, United Kingdom

Address for correspondence

Richard Harris

Institute of Education

University of Reading

London Road campus

4 Redlands Road

Reading RG1 5EX

r.j.harris@ reading.ac.uk

Tel. +44 (0) 1183782725

Biographical notes and author ORCID and Twitter details

Richard Harris

ORCID ID orcid.org/0000-0001-8606-5515

Twitter@@H47R

Richard Harris is an Associate Professor in history education at the University of Reading. His interests are mainly related to the history education, especially issues relating to the curriculum, as well as the place of diversity within the history curriculum and the public and political discourse around history education.

Suzanne Graham

ORCID ID orcid.org/0000-0002-7743-3977

Twitter : @SuzanneJaneGrah

Suzanne Graham is Professor of Language and Education at the University of Reading. She also leads its Modern Foreign Languages (MFL) Initial Teacher Education course and has taught French and German in secondary schools in England. She has researched and published widely in language teaching and learning, and language teacher development. 


\title{
Engaging with curriculum reform: insights from English history teachers' willingness to support curriculum change.
}

\begin{abstract}
The curriculum has been the target of sustained reform by many governments, and accountability measures are frequently used to compel teachers to engage with the process of change. This research aimed to explore the extent to which secondary school history teachers in England willingly engaged with a series of concurrent curriculum reforms, and the factors that shaped their level of agency in the process. Data were obtained through online surveys conducted annually from 2015 to 2017, providing over 1100 individual responses. Responses to closed items were analysed using descriptive and inferential statistics, and qualitative responses were coded to identify key themes. Generally the teachers were reluctant to engage in the process of reform. There was some statistically significant variation between teachers in different types of school, with those in state-funded schools less welcoming of change than their counterparts in private schools. Teachers' willingness to engage with changes was also related to their sense of subject identity. However it is evident that the role of accountability measures dominates teachers' thinking, not just in relation to examination courses, but also what teachers choose to do in non-examined phases of the curriculum. This appears to diminish teachers' agency when creating a curriculum.
\end{abstract}

Keywords: history education; teacher agency; curriculum; curriculum reform; teacher attitudes, values and beliefs

\section{Introduction}

Still struggling to decide whether to use Key Stage 3 [the lower secondary school curriculum] as a training ground for GCSE [upper secondary school examination course] or whether to have it sit apart and use it to offer some breadth and wider historical teaching. Heart wants the second. Head is leaning towards the first.

This comment, written by a lead history teacher in a private school, highlights the sorts of decisions many teachers across all types of schools face when confronted with curriculum change, here with reference to the lower secondary school curriculum (for those aged 1113/14 and known as Key Stage 3 or KS3) and to the upper secondary school examination course (known as the General Certificate of Education, or GCSE, for 13/14-16 year olds,). In 
this case this secondary school teacher feels torn between two options, which are seen as mutually incompatible, and can crudely be described as the tension between a focus on educational outcomes and educational values (Biesta, 2015: Holloway \& Brass, 2018).. The teacher feels there is a choice between using the time available in the lower school curriculum, when there are no examination pressures, to provide a well-rounded historical education for everyone, or using the time in the to develop the techniques and skills seen as necessary to foster success in the history examinations. Understanding how and how willingly teachers engage with such curriculum choices is at the heart of this paper.

This is an important issue because globally we are in an era of performativity (Ball, 2003), where education outcomes, such as the PISA tests, are increasingly used to measure the 'success' of education systems across a number of different curriculum subjects. In turn a focus on performativity has been underpinned by a process of constant reform (Levin, 2010) in the quest for improved outcomes. As part of this process the curriculum is a central area of focus, given that what is taught should ultimately reflect the aims and purposes of the educational system (Biesta, 2015).

The central role of the teacher in interpreting and successfully implementing such change has long been recognised (e.g. Priestley, Edwards, Priestley \& Miller, 2012), but the degree to which teachers are entrusted to do this varies across education systems. In some contexts such as Finland, teachers' professional judgements are trusted and teachers are given responsibility for developing and enacting change (Erss, 2018; Goodson, 2010). However in other contexts teachers appear to be distrusted and seen as an obstacle to reform by policymakers (Mutch, 2012; van Eekelen, Vermunt, \& Boshuizen, 2006). One response to this has been for governments to advocate evidence-based practice (to tell teachers 'what works', e.g. Blunkett, 2000) and centralised directives to govern teachers' actions and behaviours. Consequently teachers in this position are increasingly subject to 'metricized, 
marketized and managerialist processes' (Hall \& McGinity, 2015, p. 4), which are seen as de-professionalising them by undermining teachers' autonomy and freedom of action (Biesta, 2015; Wilkins, 2011). This raises the obvious question about how much freedom teachers should exercise, and recently there has been a growing interest in the role that teachers themselves could and should play as curriculum makers (e.g. Boschman, McKenney \& Voogt 2014). Lambert and Biddulph, (2015) argue teachers do not just 'deliver' a prepackaged curriculum, instead they are the ones who give life and meaning to the curriculum, which requires a complex understanding of students, the subject and pedagogy.

The focus of the present study is to understand how secondary or high school teachers engage with significant curriculum change and act as curriculum makers, especially in light of the prevailing performativity culture. Specifically this study has three foci. Firstly, some studies have suggested that some teachers may be averse to curriculum change (e.g. van Eekelen et al. 2006), in the context of a period of extensive reform it is important to assess the validity of this claim. Secondly, when implementing change, do high school teachers focus on the curricular coherence and disciplinary integrity of the subject they teach across the age ranges, or are they driven by concerns about meeting accountability measures imposed by governments? Furthermore, what factors are related to teachers' perceptions of these issues and their level of engagement with change? Finally, given that some changes, such as those related to examinations, need to be implemented regardless of whether teachers agree with them, what form of agency is manifested by teachers in the implementation of curriculum change?

Although there have been several studies examining how teachers engage with change, these studies tend to draw on small qualitative samples and take a broad non-subject specific focus (e.g. Biesta, Priestley \& Robinson, 2015; Priestley et al., 2012). This paper differs by looking at a large longitudinal dataset of responses from teachers within one 
subject community, namely history. In part this is because (as will be discussed later) the subject has been the focus of far-reaching changes to the curriculum, but also history teachers have been very engaged and responsive to debates about the curriculum (see Harris \& Burn, 2016). The data are drawn from an annual online survey conducted on behalf of the Historical Association which captures the views of over 1100 history teachers, who responded to the surveys from 2015-17.

\section{Literature Review}

Within the literature there are distinct but complementary areas of study, which will be drawn upon to examine how teachers engage with curriculum change. This review will look in particular at the role of teachers' attitudes, values and beliefs in shaping how teachers engage with curriculum reform, and the literature on teacher agency.

\section{Attitudes, beliefs and values}

It is argued that attitudes, beliefs and values are important elements in the process of implementing change and teachers tend to struggle to engage with reforms that do not fit comfortably within their view of education. As Cabello and Burnstein (1995, p. 286) comment, "[t]eachers change beliefs only if they are challenged and appear unsatisfactory. Even then ... they change beliefs only as a last alternative.' A similar point is made by van Eekelen et al. (2006) whose interviews with 15 high school teachers reveal different levels of willingness to engage with change.

It is important to acknowledge that teachers' attitudes, values and beliefs can cover a range of positions, for example views about the purpose of education generally, the merits and approaches towards teaching a particular subject, or how children learn. Some studies (e.g. Holloway \& Brass, 2018, Wilkins, 2011) suggest that many newer teachers who have been educated in a regulated education system, driven by accountability measures, are 
potentially more acquiescent when faced by reforms in such a system. This implies that such teachers have internalised messages about the educational importance of accountability and performativity, so much so that they are driven by 'short-term aspirations to tick curricular boxes, deliver enjoyable lessons, keep students engaged and interested' (Biesta et al., 2015, p. 635) and are unable to articulate a counter discourse focused on the longer term values and purposes of education.

The attitudes, beliefs and values that inform a teacher's world-view can also become embedded into a sense of self and therefore become an integral part of professional identity (Pajares, 1992). Therefore changes which potentially are in conflict with a teacher's core values and sense of self can be seen as threatening (e.g. Mitchell, 2016). A particular issue of interest, in this study, is the role that a teacher's subject specialist identity plays in how they engage with curriculum change. For many secondary school teachers, attitudes, beliefs and values about their specialist subject can play a significant role in their overall sense of professional identity (e.g. Rogers, 2011) because their experience, level of interest and depth of study have often helped to forge strong convictions about the value of the subject and how it should be taught. Yet the research into the role of subject identity in relation to change, such as Mitchell's (2016) study of four geography teachers, is based on very small samples, whereas the findings reported in this study are based on a larger sample.

Linked to ideas about beliefs and attitudes is teachers' perception of 'risk' (Le Fevre, 2014). Many reforms could be considered high risk, and although accountability measures (such as examination outcomes) may be used as a means of arms-length governance to encourage teachers to adopt particular reforms, fear of failure may restrict what teachers are prepared to do. The risk of change may jeopardise meeting an accountability measure, and this may inadvertently act as a disincentive. 


\section{Teacher agency}

Agency is seen as another important component in the process of determining what change occurs, and is also seen as being informed by attitudes, beliefs and values (Biesta, et al., 2015). In theories about agency a key debate is about the degree of agency that it is possible to exert.

One side of the debate stresses individual agentic power. Fenwick (2003) argues that teachers who have a sense of ownership of educational changes, based in their personal needs, feel empowered to implement change and changes will only be successful if they are aligned with teachers' educational attitudes, beliefs and values and/or are self-initiated. But even this position is complex. Hargreaves' (2004) study, drawing on interviews with 50 Canadian teachers, highlights the negative response of teachers to mandated change, and the more enthusiastic engagement with self-initiated change, but his study shows about half of the self-initiated plans sprang from the need to meet mandated reforms. In both these studies the emphasis is on the role of the individual as being the mechanism for (or obstruction to) change. At the other end of the spectrum teachers are viewed as technicians, accepting and implementing change without any sense of mediation (e.g. Wilkins, 2011). In this view it is structural and contextual factors that drive change. Both of these views tend to underplay the interaction between the individual and the context. An alternative perspective is a relational view of agency, which stresses the interaction between the individual, available resources and contextual/structural factors, such as Biesta and Tedder's (2007) ecological model. These authors argue that agency is not related to personal capacity, it is not something that anyone has per se. Instead it is regarded as an achievement arising from transactions of an individual within the contingencies of a specific environment. The school and/or policy context can therefore play an important constraining or liberating role in teachers' ability to achieve agency at a particular moment in time. The transactional nature of agency within this model 
also helps to explain why teachers are able to demonstrate differing levels of agency at different times.

Priestley et al. (2012) and Robinson (2012) also highlight the temporal dimension of agency. This recognises that individuals have past experiences (iterative) and future aspirations (projective) - both of which shape teachers' attitudes, beliefs and values - that intersect with current policy texts and initiatives to determine what happens in the immediate present (practical-evaluative). This also helps to explain why a teacher's achievement of agency may be fluid, as teachers negotiate their way through policy landscapes to find a position with which they are able to work.

This temporal dimension of agency identifies various factors that may shape how a teacher engages with curriculum change. The iterative and projective aspects that shape agency are likely to be influenced by a teacher's attitudes, beliefs and values associated with their specialist subject area. In addition a teacher's experience is likely to be shaped by their career stage and role within school and therefore how willingly teachers engage with curriculum change. For example Hargreaves (2005) argues that early career teachers are more adaptive to change. He also argues that experienced teachers adopt different positions in relation to change and categorises, which range from the 'renewed', the 'positive focusers', the 'negative focusers' and the 'disenchanted'. The practical-evaluative element largely involves the context within which change is occurring. This may be linked to what Braun, Maguire and Ball (2010) refer to as 'situated' (e.g. socio-economic factors such as nature of the intake, local area), 'material' (e.g. staffing levels, financial resource) and 'external' (levels of support from external agencies, reputation) factors. Previous studies (e.g. Harris \& Burn, 2011) have also shown that responses to curriculum reforms vary by school type, another 'situated' factor of relevance in contexts such as England where a range of school types exist (see below). 
What this literature highlights is the complexity of educational change, and the role of teachers within that process. This study adds to the literature by exploring how a large number of specialist secondary school teachers, engage with a process of curriculum reform, whether they welcome the changes and what are the various factors that shape how agency is achieved.

\section{Context}

The context for this study is England, at a time in which secondary school teachers were faced by three significant curriculum policy changes.

From 2015 secondary school teachers in England were required to implement new examination courses for students aged 16-18, known as A levels (for first examination in 2017) and modify the lower school curriculum (known as Key Stage 3 or KS3) for students aged 11-13/14. Further changes were introduced to the examination courses, called GCSEs, for students aged 13/14-16, with approval for new specifications being given for first examination in 2018. In England teachers can choose a course from different examination boards; the courses need to meet agreed subject specific criteria to be approved, but teachers then can choose between the different examination board's specifications. The simultaneous and extensive reform of the curriculum meant that teachers were faced with wholescale change. The government's rationale for the changes was to bring new content into many subject areas, and to make the examinations more challenging (Gove, 2014).

At the same time teachers were facing new accountability measures. The changes to the national reporting of GCSE examination results are probably the most significant. For example schools were originally judged on how many students achieved five good passes (grades $\mathrm{A} *$ to $\mathrm{C}$ ). Later, in 2005, an additional measure was added meaning that schools had to report the number of students whose five good passes included English and mathematics. 
More recently schools are also expected to report on how many students get five good passes in a narrow range of perceived 'academic' subjects (English, mathematics, a science, a humanities subject and a modern language), under the so-called English Baccalaureate or EBacc.

In the subject area on which this paper focuses, history, the curriculum changes were particularly radical and in some ways contentious. History is often seen as a politicised subject area, because of its perceived role in shaping national identity and social cohesion, and curriculum changes can spark varying degrees of hostility (e.g. Nakou \& Barca, 2010). The proposed changes to the lower school curriculum re-ignited debates about content, especially what British history should be studied, and the degree of prescription about what should young people know, and whether history should be taught as a body or form of knowledge (e.g. Harris \& Burn, 2016). After a period of intense consultation a less contentious curriculum was introduced (Smith, 2017). However there were other radical changes, for example in the GCSE examination. Prior to the changes, the most commonly studied course focused on twentieth century world history, whereas under the new specifications all students have to study history from the medieval, early modern and modern periods. Also this history must cover local, national and global aspects of the past, and different time spans. This means students study some topics in depth, others in more breadth and others as a development through time. Consequently, teachers and students would be expected to cover more historical content, from a range of different times and places, and study history on different scales.

The study addresses the following specific research questions:

1. To what extent do history teachers embrace curriculum change, and how does this differ according to: a) the type of school in which they work; b) their length of teaching experience/role; and c) the nature of their school intake? 
2. What issues do teachers identify as important in the face of change? To what extent do these vary by school type and teacher experience/role?

3. How is agency manifested by teachers in the implementation of curriculum change?

\section{Methodology}

The data for this paper are drawn from an annual online survey, co-created by the first author of this paper, and conducted on behalf of the Historical Association. The survey started in 2009 but this paper focuses on 2015-2017 because of the degree of curriculum changes being imposed on schools during this period.

\section{Sample}

The sample for this study is 1102 history teachers in secondary schools in England (see Table 1). All schools in England are sent the survey annually in the late spring/early summer and the history teachers in each department are asked to complete it. This means that in some cases multiple responses can be received from a school, and also that a school may respond to the survey over a number of years. However the analysis in this paper is focused on teachers' individual perspectives, rather than on a school perspective, and in the main looks at results by and across particular years. This approach was taken to minimise the danger that responses from any one school which contributes regularly to the survey might skew the findings.

In total there are about 3400 state-funded secondary schools in England. These include non-selective types of school, and grammar schools which select pupils by ability at the age of 11/12, as well as sixth form colleges, which only admit learners aged 16-19. In addition there are around 500 private schools attended by secondary aged students, which are 
fee-paying and typically select learners by ability and generally have more autonomy than state-funded schools. On average responses to the survey are received from around $10 \%$ of schools each year. Despite this relatively low response rate, this dataset is the largest of its kind and does provide an overview of developments within history education in schools in England.

[insert Table 1 near here]

It is important to acknowledge that the curriculum reforms discussed in this paper occurred at a time when there was a significant change in how schools were designated and funded, which makes it challenging to define the sample regarding non-selective schools. Traditionally most non-selective schools in England would be classified as comprehensives. However since 2002 comprehensive schools could become 'academy' schools; essentially instead of being funded and accountable to local government, academies are funded directly from central government. Initially the designation was purely for some comprehensives in areas of socio-economic deprivation, but since 2010 there has been a government push to convert all comprehensive schools into academies. Many of these academies are now part of 'multi-academy trusts' (or MATs), where groups of schools are managed collectively (often by private or charitable organisations). Academies do not have to follow the National Curriculum that applies to the lower school, but follow GCSE and A level courses in the same way as other schools. In addition there are now 'free' schools set up by individuals or groups, which are similar to independent schools but are publicly funded and are supposed to take a mixed social and ability intake (DfE, 2014). For the purposes of this study the responses for all non-selective schools have been combined under the heading 'comprehensive'. On the one hand this was because very few responses were received from teachers in free schools, on the other because the on-going conversion of comprehensives into academies means the boundaries between these types of schools is increasingly blurred. 
Preliminary analyses of these school types separated out did not, furthermore reveal any major differences, supporting the decision to combine them into one group.

\section{Instrument: The survey}

The length of the survey varied from year to year. In 2015 and 2016 it consisted of 51 questions in total, and in 201753 questions. Some questions are asked year on year to check on possible trends in schools, e.g. asking about time allocation for history in the curriculum, but other questions are specific to issues that arise from changes in government policy and it is these items that are reported on here. While the survey does not always ask direct questions about teachers' attitudes, beliefs and values or agency, the questions were designed in a way to elicit such data more indirectly. For example asking teachers about what influenced their choice of examination specification provides an insight into their values and priorities. Figure 1 indicates which questions were asked and in which survey year. Most items in the survey are discreet response points that were coded numerically to enable SPSS analysis. [insert Figure 1 near here]

In all three of the surveys teachers were asked to explain what impact the introduction of the new examination courses was having on the lower school curriculum; this was to explore the dilemma teachers appear to face in determining whether the non-examined lower school curriculum should be used primarily as preparation for the examination courses. Teachers were given a 4 point Likert scale, with 1 indicating the changes were having profound impact on the construction of the lower school curriculum, and 4 indicating the impact was non-existent. Teachers were then given a list of eight possible impacts and asked to identify any that applied to their decision making (Figure 2).

[insert Figure 2 near here] 
In terms of questions that varied across years, in 2015 one question presented ten items and teachers were asked to indicate, on a scale of 1 to 4 , their reactions to aspects of the proposed changes, with 1 indicating that they welcomed the change, 4 that they had serious concerns (see Figure 3). Three of these items related to practical issues, three concerned the nature of the exam, and the remainder were designed to gain insights into teachers' attitudes regarding the nature and value of the history that would be taught.

[insert Figure 3 near here]

Another two questions asked teachers to say whether or not they welcomed the changes to GCSE and A level as a whole. Altogether these responses were designed to provide an insight into teachers' reactions to the changes as they were coming into effect.

These questions were then followed up in 2016 and 2017 by questions designed to explore whether teachers' responses to the curriculum changes became more positive as they became more familiar with the changes. Teachers were asked to rate their experience of the new GCSE and A level examinations respectively, using a 4 point Likert scale, with 1 indicating a high level of positivity, 4 a low level.

In 2015 teachers were also asked to indicate which factors influenced their choice of examination specification at GCSE and A level, choosing from 11 possible factors for GCSE board and ten for the A level. Respondents were asked to select all factors that they felt applied to them (see Figure 4).

[insert Figure 4 near here]

In all three surveys teachers were given open comment boxes where they were invited to explain some of their responses. These were largely used in conjunction with yes/no question responses and were designed to give a more qualitative insight into issues relating to research question one. In these cases comments were coded into themes.

Finally, respondents were asked about teacher factors of interest for this paper, namely length of teaching experience and the teacher's role in the school. They were also 
asked for information relating to their school's 'situated' characteristics: type of school (e.g. comprehensive, grammar, independent) and for the school postcode. The latter was used to obtain a measure of socio-economic status (SES) for each school based upon an Income Deprivation Affecting Children Index (IDACI) (see http://imd-bypostcode.opendatacommunities.org/ ), which provides a score and rank for social deprivation for each postcode in England. IDACI ranks and scores can generally be used as a proxy measure for assessing the SES nature of a school's intake (although there are some caveats that need to be considered, as some areas have pockets of deprivation that may not be picked up in a generally affluent postcode area).

\section{Analysis}

In order to answer the first research question regarding teachers' openness to change, a measure of total 'openness to change' and then a mean 'openness to change' score was calculated. These were computed by summing responses to the ten items, from the 2015 survey, asking teachers for their reactions to aspects of the proposed changes and then dividing by ten. The resulting mean 'openness to change' score, was e considered to be an interval variable and Cronbach's Alpha (.946), indicated a high level of internal consistency for it.

Normality and homogeneity of variance assumptions were assessed by examining histograms and normality tests. Normality tests (Shapiro-Wilks) indicated that the mean openness to change scores were not normally distributed: S-W .98, df $357, \mathrm{p}<.0001$. The histogram suggested however that deviations from normality were not severe and following Field (2013), it was decided that parametric tests were robust enough to cope with the slight deviations from normality for this score (with assumptions for each individual test checked and reported separately under Results). 
For individual items in the questionnaire that were of ordinal or categorical nature non-parametric statistics were applied in any analyses. Unless indicated, in all cases the alpha level was set at .05. Results for Bonferroni post-hoc tests are reported using SPSS Bonferroni adjusted p-values, i.e. adjusted for multiple comparisons. For chi-square analyses, results from post-hoc adjusted residual tests are reported.

\section{Results}

1. To what extent do history teachers embrace curriculum change, and how does this differ according to: a) the type of school in which they work; b) their length of teaching experience; and c) the nature of their school intake?

Simple descriptive statistics and frequencies were firstly calculated for the mean openness to change score, for all schools and then for each school type.

An overall mean score of 2.5 or lower would indicate a generally high level of readiness to embrace change. Table 2 shows that overall teachers were not open to change, although the range is quite large. Only $23.5 \%$ of all teachers had a mean response of 2.5 or below. Teachers in independent schools were the most open to change, and those in comprehensive schools the least. A one-way ANOVA (Levene's test, $\mathrm{p}=.594$ ) indicated that differences across school type were statistically significant $(\mathrm{F}(2,354)=6.851, \mathrm{p}=.001)$. Bonferroni post hoc tests revealed that independent school teachers' openness to change was greater than that of comprehensive school teachers at a statistically significant level $(\mathrm{p}=$ .001 ). Around $37 \%$ of teachers from independent schools indicated an overall positive response to the changes compared to around $21 \%$ of comprehensive school teachers . There were no further statistically significant differences between the other school types. Turning to teacher variables, Spearman rank order correlations (used because teacher experience was on an ordinal scale) revealed a weak but statistically significant relationships between mean 
openness and length of teaching experience $(r=.116, p=.028)$ and role in school $(r=.106, p$ $=.045)$, indicating that newer teachers and those in less senior positions were more open to change as a whole. A correlational analysis of a school's IDACI ranking indicated there was no statistical relationship between a teacher's willingness to embrace change and the socioeconomic status of the school catchment area.

[Insert Table 2 near here]

Teachers were also asked directly in the 2015 survey whether they welcomed the changes at GCSE and A level. In both cases the majority of teachers did not welcome the changes, but the changes to the GCSE were slightly more positively received (56\% negative, 44\% positive from the 373 respondents answering the question). There was little variation across school types, but more by length of teaching experience. Only $21 \%$ of newly qualified teachers (NQTs) welcomed the change to GCSE with 79\% against (from a small total number of respondents who identified as NQTs, i.e. 19). Responses by role in school also showed some variation, with only $37 \%$ of main-scale teachers welcoming the change, compared with $47 \%$ of lead history teachers and $42 \%$ of those on the senior leadership team who said they did. This suggests that newer and more junior members of the teaching team feel less comfortable with the changes for examinations specifically. There was however no statistically significant differences by type of school, length of teaching experience or role in school, as explored through chi square tests. Nor was there any statistically significant relationship between a school's IDACI decile ranking and whether teachers welcomed the changes.

Descriptive statistics suggest there was more negativity around the changes to the A level. Only $33 \%$ of the whole sample $(n=97)$ said they were looking forward to the changes with 66\% (192) not looking forward to them. Those in sixth form colleges (75\%) and comprehensive schools (69\%) were the most concerned, compared to $58 \%$ of respondents in 
independent schools and 55\% of those in grammar schools. As with the GCSE changes, less experienced teachers tended to be most concerned; 73\% of NQTs were unhappy, as were $75 \%$ of those with $1-5$ years' teaching experience, compared with $64 \%$ of more experienced colleagues. There was little difference according respondents' role in school, with around two-thirds of respondents in each role category not looking forward to these changes. There were no statistically significant differences between any of the respondent groupings.

To explore whether teachers felt positive about the changes to the examination courses once they had become more familiar with them teachers were asked to rate their experience of the new GCSE in 2016. In 2016 and 2017 they were asked to do the same for the A level. In all years responses were on a four point scale, but for the GCSE there was a fifth option, 'too soon to tell'. Nearly $70 \%$ of responses to the GCSE question chose this fifth option making it difficult to draw clear conclusions about this change. Of those that did respond using the other options, $7 \%$ said it had been a positive experience compared to $2 \%$ who said it had been mainly negative. A further $18 \%$ described the experience as mixed.

A fuller set of responses were given for the A level question. Overall 35\% claimed the experience was mainly positive, compared to $6 \%$ who said it was negative. Most however, $53 \%$, said the experience had been mixed. A Kruskal-Wallis test revealed no statistically significant differences between school types or by teachers' length of experience or role in school. There were however differences between the responses in the two years. In $201630 \%$ of responses indicated that teaching the new A level had been a positive experience, but this figure had risen to $40 \%$ in the 2017 survey. In contrast those who reported a mixed or negative experience had dropped from around $61 \%$ in 2016 to $56 \%$ in 2017 (see Table 3). However a Wilcoxon signed rank test indicated there was no statistical significant difference between the two years $(\mathrm{p}=.224)$. The responses for GCSE and A level were also combined to generate an overall mean score for the experience of these changes, with a score of 2.5 or 
lower indicating either a positive overall experience or a sense that the changes had made little difference to the teachers' experience. In total around $43 \%$ of teachers scored 2.5 or less, indicating that many teachers were positively inclined to the changes, although respondents were more favourable about the changes to the A level course. Overall these figures suggest that teachers become more favourably disposed to curriculum change as they have greater experience of teaching new courses.

[insert Table 3 near here]

2. What issues do teachers identify as important in the face of change? To what extent do these vary by school type and teacher experience/role?

Teachers were asked in 2015 to indicate how positive they were to a number of individual aspects of changes within the examination curriculum. Only those related to subject content received positive or fairly positive responses. The introduction of a thematic study (with an overall mean score of 2.22) was the most popular change. The study of the historic environment (mean score of 2.56) was also relatively well received. The most serious concerns were reserved for more practical issues such as levels of funding to implement changes (3.51) and the suitability of the changes for lower attaining students (3.32) (see Table 4). A comparison of responses by school type (Kruskal-Wallis tests) suggested statistically significant differences for concerns about levels of funding and suitability for lower attaining students among the different school types. The main differences seemed to lie between teachers from independent $(\mathrm{Mdn}=3.00)$ and comprehensive schools $(\mathrm{Mdn}=4.00)$ for concerns over funding, and between comprehensive schools $(\mathrm{Mdn}=4.00)$ and the other two school types (independent schools, $\mathrm{Mdn}=3.00$; grammar schools, $\mathrm{Mdn}=2.50$ ). Post-hoc Mann-Whitney U tests, however, with a Bonferroni correction (reducing the alpha level to .017) indicated a statistically significant difference only between comprehensive school teachers and grammar school teachers regarding suitability for lower attaining learners $(\mathrm{U}=$ 
$4365.50, \mathrm{p}<.001)$.

[insert Table 4 near here]

Examining the open-ended responses to some of the questions gives further insight into elements of the changes that teachers considered important. Teachers had an opportunity to explain what they were looking forward to in the new courses. For the GCSE, 164 out of 444 teachers gave a response and the majority of these, 121, highlighted the opportunity to teach new areas of content as positive. The move towards summative assessment only and the introduction of the local historic environment were the next most positively received, but attracted only around 20 comments each, so appear to be less significant in terms of teachers' reactions. This suggests that curriculum changes that focus on the subject content - in this case new periods of history - are more welcomed, presumably as this broadens students contact with aspects of the subject.

Similar results were also noticeable with the changes to the A level course. Of 97 teachers who said they were looking forward to the changes the most common comment was related to the opportunity to teach new topics, mentioned by 57 teachers. A further 15 welcomed the requirement to cover a broader timespan of history and 11 welcomed the move towards end of course exams (as opposed to having exams at the end of the first and second year) as this gave them more teaching time.

In 2016 and 2017, teachers also had an opportunity to give an explanation for their response relating to their experience of change as they became more familiar with the GCSE and A level courses. Table 5 indicates the number of teachers who provided positive and negative responses. The most positive comments were related to subject specific issues, whereas the majority of negative comments, which were more frequent, were linked to factors that would influence examination outcomes. In 2016 the chance to teach new content at GCSE was the most frequent positive comment, mentioned 15 times, whilst a further 11 
teachers were pleased to be able to teach topics that were familiar to them. However there were more negative observations, the most common complaint being about the lack of appropriate textbook resources being available in time for teaching the new examination course. A further 21 responses stressed the lack of assessment examples teachers could use to gain a sense of the expectations for the exam papers. Alongside these were eight explicit observations about the lack of clarity regarding grading criteria. Teachers were also asked to provide comments about their experience of the GCSE changes in 2017, which saw stronger negative reactions. Thirty comments were linked to the lack of assessment examples and 24 with grading issues. In addition there were a significant number of comments relating to the nature of the course; 25 teachers expressed concerns about how much content they were required to cover in the time and 17 felt that the amount of material made the course inaccessible for lower attaining students. A similar trend can be seen in the responses relating to the changes at A level, with the number of criticisms growing in 2017. Although the teachers remarked favourably on the new content that was to do be taught, there were concerns about poor availability and quality of textbooks, a lack of clarity over grading criteria and the amount of content that was expected to be taught and mastered. [insert Table 5 near here]

3. How is agency manifested by teachers in the implementation of curriculum change?

Given the significance of the changes being introduced to the GCSEs and A levels from 2015 teachers were asked to identify from a range of factors those that had influenced their choice of examination board, so that insights could be gained into the ways in which they exercised at least some agency over what was taught. In total 430 teachers responded to the question about the GCSE and 301 for the A level (the difference in numbers is largely because some schools do not admit learners beyond age 16 so do not teach A level courses). Table 6 shows responses by order of frequency and indicates that teachers' actual choice of exam course is 
largely determined by pragmatic considerations and a focus on obtaining good examination results. Factors such as choosing topics based on their importance to young people's understanding of the world would reflect a concern with the value and purpose of the subject, yet such a concern was highlighted by fewer than a quarter of teachers as a reason for choosing an exam course. Similarly factors such as the teaching of the historic environment and conducting a personal investigation, which are related to the nature of history, rate low on these teachers' priorities.

[insert Table 6 near here]

A chi square test was conducted to determine whether there was any variation by school type across the top four factors identified for the GCSE, all of which were essentially related to maximising examination success and/or resource implications. Post hoc chi square adjusted residual tests showed that comprehensive schools were significantly more likely $(\mathrm{p}=$ .00026) to choose an exam based on their prior experience with the board than independent schools. Independent schools were significantly less likely to be take into consideration students' interest in the topics offered by an exam board $(p=.00061)$. The need to minimise resources for a new course were significantly higher for comprehensives $(\mathrm{p}<.0001)$ compared to independent schools where this was a lesser issue. Chi square analyses revealed no significant variation by a teacher's length of service or role in school. Nor was there was any statistical variation in the factors that influenced choice of A level examination courses according to school type, teacher experience or role.

Although the data just presented show that what is taught in the lower school (KS3) curriculum is not a major factor in the choice of GCSE, in other responses how the choice of GCSE impacts on what happens at KS3 is clear. Each year teachers were asked, using a 4 point scale, what impact the GCSE changes were having on the lower school curriculum, with 1 indicating a profound impact. Only $30 \%$ of respondents said there was no or limited 
impact. Most teachers reported the impact as considerable - $49 \%$ - with another $21 \%$ saying it was profound. A comparison of school responses (Kruskal-Wallis tests) indicated some statistical differences between school types $(\mathrm{p}=.024)$, even though the median responses were identical - comprehensive $(\mathrm{Mdn}=2.00)$, grammar $(\mathrm{Mdn}=2.00)$ and independent schools $(\mathrm{Mdn}=2.00)$. Further analysis using a post-hoc Mann-Whitney U test (with a Bonferroni correction reducing the alpha level to .017) highlighted a statistically significant difference between comprehensive and independent schools $(U=29344.00, p=.006)$. Further analysis also shows that there is a significant difference identified by year. The degree of influence of the GCSE on the lower school curriculum, using a Wilcoxon signed rank test, was judged to be more profound in 2017 than $2015(\mathrm{p}=.004)$. The reason for this is not entirely clear but may be to do with the fact that teachers were becoming more aware of the requirements of the GCSE by 2017 and so were starting to rethink more seriously what might need to be changed at KS3.

Teachers were given a list of eight ways in which GCSE might affect the lower school curriculum (see Figure 2) and asked to identify all those that were relevant in their context. These factors were included in the survey as a possible indication of whether teachers saw the lower school curriculum as a means of enhancing examination success at GCSE for the minority of students who would study it at that level or were focused on providing a rounded historical education for all pupils. Responses suggest that the first of these two aims was the more important for teachers, especially in comprehensive schools. For example, around 40\% of comprehensive schools reported revisiting the same content at both KS3 and GCSE, compared to only $16 \%$ of independent schools. Similarly, KS3 was reported to be used as an introduction to the GCSE course for $48 \%$ and $25 \%$ of respondents from the two school types respectively. Chi square tests followed by post hoc adjusted residuals tests showed both of these differences to be statistically significant $(\mathrm{p}<.001)$. 
The data also suggest that assessment issues at GCSE were dictating approaches at KS3. Nearly two thirds of teachers in the lower school reported using GCSE style questions to assess students in KS3. This was particular true in comprehensive schools and grammar schools where around 70\% of teachers were using GCSE style questions in the lower school curriculum, compared to a third of teachers in the independent sector $(\mathrm{p}<.0001)$. The way GCSE approaches dominate KS3 assessment is also suggested by the fact that around half of all respondents reported adapting how they teach KS3 students to use sources and understand historical interpretations; both of these elements are important components of the new GCSE examinations. This was especially true in comprehensive schools where it was more frequently reported than in independent schools $(\mathrm{p}<.0001)$.

\section{Discussion}

Our first research question asked to what extent do history teachers embrace curriculum change, and how does this differ according to: a) the type of school in which they work; b) their length of teaching experience/role; and c) the nature of their school intake. Overall the teachers who responded to these surveys did not warmly welcome the curriculum reforms and this reinforces the view that teachers can be resistant to change (e.g. van Eekelen et al., 2006). One possible explanation for this reluctance to embrace change may be the wholesale, extensive nature of these particular changes, and the resultant impact on teachers' workload. Nevertheless, the variation by school type in openness to change suggests that performativity measures, whereby teachers in state-maintained comprehensive schools are under greater public scrutiny of examination results compared to their counterparts in the independent sector, are a factor that inhibits the embracing of change. However it seems that some 'situated' factors, such as the socio-economic status of the area, (Braun et al., 2010) are not significant in how teachers engage with reform. This suggests that pressure of change is 
being felt across the state-maintained sector, and is not related to specific geographical areas.

There is also some indication that newer teachers or those in more junior roles are slightly more open to change. The reasons for this are not entirely clear but may stem from more experienced teachers having dealt with numerous initiatives throughout their career and simply being tired of seemingly endless change (Hargreaves, 2004). It is also possible that newer teachers, who have most probably been educated in a performativity culture, have accepted discourses about the necessity of particular forms of change (Holloway \& Brass, 2018; Wilkins, 2011). An alternative explanation may relate to teachers' intellectual confidence. Counsell (2011) argues that intellectually confident teachers have a stronger sense of what matters in their subject area, which would most likely have accrued over time, so are only likely to respond positively to change that fits in with their attitudes, beliefs and values (relating to history education in this instance). This explanation seems possible given that the teachers who responded to the surveys were more positive about changes directly related to opportunities to teach new topics, offering students a broader historical education. This in turn would imply that for curriculum reforms to be embraced by subject specialist teachers, careful consideration needs to be given to how any such reforms should reflect the nature of the subject (Mitchell, 2016).

This idea is further supported by the fact that changes to GCSE were more positively received than those to A levels. This suggests that change is not necessarily rejected per se, but depends on the nature of the proposed change. In England there has been discontent within sections of the history education community about the history GCSE for some years; for example Culpin (2002) attacked the Modern World History GCSE course for being neither particularly modern nor genuinely focused on world history, whilst Kitson, Husbands and Stewart (2011, p. 51) describe history teachers' frustrations about 'the seemingly dire state of GCSE'. Consequently reforms that reflect teachers' desire for change are embraced 
more sympathetically. However what is clear is that any positivity from teachers about new content they can teach is offset by concerns about specific aspects of the new course - in particular the teaching of historical interpretations, the use of source work and the perception of content overload for students.

Addressing our second research question, the issues that teachers identify as important in the face of change and the extent to which these vary by school type and teacher experience/role, it would seem that some teachers are operating with a 'split' identity. Many teachers seem open to change where proposals are in tune with the attitudes, beliefs and values that inform their subject identity, but being proficient in maximising student outcomes has become an important objective in the current educational climate and appears to dominate the actions of many teachers, especially in comprehensive schools. The dominance of a performativity discourse, focused frequently on teachers understanding assessment criteria, highlights the way accountability measures are impacting on education (Hardy, 2018). Factors relating to the value, purpose and nature of history were not significant priorities in most history teachers' decision making. It would seem that the short-term goal of examination success has become the main indicator of a 'good' education, rather than cultivating the longer-term goal of the educational value of the subject being studied (Biesta, 2015; Biesta et al., 2015).

Turning to our third research question, how is agency manifested by teachers in the implementation of curriculum change, it is clear that the policy and school context is acting as a constraint on what teachers feel able to do. Teachers' actual choices about examination course, where they might show some agency, are dictated by 'material' issues (Braun et al., 2010), rather than considerations for the subject. Where teachers are freer from examination constraints in the lower school curriculum, where it would be possible to enact values about the educative power of history, There is a clear 'back wash' effect from the examination 
courses. Teachers reported choosing content and particular approaches to history teaching at KS3 based on what happens at GCSE (even though students do not have to study history at GCSE). Another issue is that accountability measures would appear to curtail creativity and innovation in teaching, as teachers fear doing something different that might jeopardise outcomes. As Parsons, Parsons, Morewood and Ankrum (2016, p. 374) highlight, teachers may need 'different pedagogical approaches to instruction' in the face of change. Yet the existence of strong accountability measures mean many teachers look to the comfort of having already worked with an exam board, teaching familiar topics and maintaining tried and tested approaches to teaching. This suggests perhaps an aversion to risk (Le Fevre, 2014). This is not to say that teachers do not take their role seriously but that their horizons of what is educationally possible, and therefore the nature of the agency they enact, become restricted by the focus on accountability outcomes.

\section{Conclusion}

Overall this study shows a degree of reluctance on behalf of these teachers, to engage with curriculum reform, but at the same time these teachers, especially in the non-selective sector, have internalised the culture of accountability and performativity. In these contexts curriculum change is largely discussed in terms of examination outcomes, whilst any sense of the educational value of studying history appears suppressed. This can also be seen in the thinking of history teachers in other education systems (e.g. Ormond, 2016). Although the data in this paper relate to one specific curriculum area, it is seems likely that the issues highlighted would be replicated in other subject areas. Indeed Graham, Santos and FrancisBrophy (2014), in England, and Lee (2008) in Hong Kong, have report evidence of accountability concerns seeming to dominate teachers' classroom practice, often in contradiction to their stated beliefs about what is important in language teaching. 
According to Biesta et al. (2015, p. 635) a focus on results can lead to 'an impoverishment in teacher discourses, which potentially reduces their agency.' This can be seen in many of the complaints put forward by teachers in the survey. They appear largely concerned about a lack of resources, either from publishers or exam boards, and a lack of clarity and guidance over exam expectations. This suggests a dependency by teachers on others for success in the exams, an apparent abdication of their responsibilities. It also suggests a diminished sense of teacher judgement and agency, as teachers feel only able to exercise this in relation to meeting accountability measures, and even here their room for exercising judgement appears constrained. The fact that meeting performance targets is extending itself into areas of the curriculum that are not technically part of those targets (i.e. the way the lower school curriculum is being used to prepare students for their examinations) suggests educational values are being distorted for the means of a narrow set of performance outcomes. For Biesta (2015) this is not 'good' education for young people, whilst for Erss $(2018, p .1)$ the lack of teacher autonomy is a concern as 'autonomy is one of the basic psychological needs supporting motivation and job satisfaction'. Neither are necessarily arguing for complete teacher control over the curriculum, but more of a readjustment where teachers' professional judgement is more strongly respected and able to be exercised, and a better balance between central direction and local autonomy.

It would seem that the combination of extensive curriculum reform and the pressure to attain good examination results means that teachers, struggling to come to grips with new course expectations, become risk averse, which in turn undermines their degree of agency. By focusing on short term examination success, teachers' agency becomes further limited to what is seen as educationally valuable in a performativity culture (Biesta et al., 2015). It appears that curriculum reform designed to improve academic outcomes is likely to be circumscribed by the very accountability measures designed to measure any improvement 
and limits the role teachers play in achieving agency when enacting curricula. With this comes potentially the risk of undermining and undervaluing the importance of allowing teachers to exercise genuine educational judgement. This in turn is likely to make it harder in future for teachers to have the experience from which they can draw to use that judgment effectively in their practice.

\section{References}

Ball, S. J. (2003). "The Teacher's Soul and the Terrors of Performativity." Journal of Education Policy, 18 (2), 215-228.

Biesta, G. (2015). What is education for? On good education, teacher judgement, and educational professionalism. European Journal of Education, 50 (1), 75-87.

Biesta, G. J. J., \& Tedder, M. (2007). Agency and learning in the lifecourse: Towards an ecological perspective. Studies in the Education of Adults. 39, 132-149.

Biesta, G., Priestley, M. \& Robinson, S. (2015). The role of beliefs in teacher agency. Teachers and Teaching, 21 (6), 624-640.

Blunkett, D. (2000). Influence or irrelevance: Can social science improve government? London: Department for Education and Employment.

Boschman, F., McKenney, S., \& Voogt, J. (2014). Understanding decision making in teachers' curriculum design approaches. Education Technology Research Development, 62, 393-416.

Braun, A., M. Maguire and S. Ball. (2010). "Policy Enactments in the UK Secondary School: Examining Policy, Practice and School Positioning." Journal of Education Policy, 25 (4), 547-560.

Cabello, B. and Burstein, N. D. (1995). 'Examining Teachers' Beliefs about Teaching in Culturally Diverse Classrooms'. Journal of Teacher Education, 46 (4), 285-294.

Counsell, C. (2011). Disciplinary knowledge for all, the secondary history curriculum and history teachers' achievement. The Curriculum Journal, 22 (2), 201-225.

Culpin, C. (2002). Why we must change history GCSE. Teaching History, 109, 6-9.

DfE (2014). Free school admissions guidance Mainstream admissions. Retrieved from https://assets.publishing.service.gov.uk/government/uploads/system/uploads/attachment_data /file/389813/Free_School_Admissions_Guidance.pdf

Erss, M. (2018) 'Complete freedom to choose within limits' - teachers' views of curriculum autonomy, agency and control in Estonia, Finland and Germany. Curriculum Journal (online). 
Fenwick, T. (2003). 'The 'good' teacher in a neo-liberal risk society: a Foucaultian analysis of professional growth plans'. Journal of Curriculum Studies, 35 (3), 335-354.

Field, A. (2013). Discovering statistics using IBM SPSS statistics. London: Sage.

Goodson, I. (2010). Times of educational change: towards an understanding of patterns of historical and cultural refraction. Journal of Education Policy, 25 (6), 767-775.

Gove. M. (2014). GCSE and A level reform. Retrieved from https://www.gov.uk/government/speeches/gcse-and-a-level-reform

Graham, S., Santos, D., \& Francis-Brophy, E. (2014). Teacher beliefs about listening in a foreign language. Teaching and Teacher Education, 40, 44-60.

Hall, D., \& McGinity, R. (2015). Conceptualizing teacher professional identity in neoliberal times: Resistance, compliance and reform. Education Policy Analysis Archives, 23 (88), 1-17.

Hardy, I. (2018). Governing teacher learning: understanding teachers' compliance with and critique of standardization. Journal of Education Policy, 33 (1), 1-22.

Hargreaves, A. (2004). Inclusive and exclusive educational change: emotional responses of teachers and implications for leadership. School Leadership \& Management, 24 (3), 287-309.

Hargreaves, A. (2005). Educational change takes ages: Life, career and generational factors in teachers' emotional responses to educational change. Teaching and Teacher Education, 21, 967-983.

Harris, R., \& Burn, K. (2011). Curriculum theory, curriculum policy and the problem of illdisciplined thinking. Journal of Education Policy, 26, 245-261.

Harris, R., \& Burn, K. (2016). English history teachers' views on what substantive content young people should be taught. Journal of Curriculum Studies, 48 (4), 518-546.

Holloway, J. \& Brass, J. (2018). Making accountable teachers: the terrors and pleasures of performativity. Journal of Education Policy, 33 (3), 361-382.

Kitson, A., Husbands, C. \& Steward, S. (2011). Teaching and learning history 11-18. Maidenhead: McGraw Hill.

Lambert, D., \& Biddulph, M. (2015). The dialogic space offered by curriculum-making in the process of learning to teach, and the creation of a progressive knowledge-led curriculum. Asia-Pacific Journal of Teacher Education, 43 (3), 210-224.

Lee, I. (2008). Understanding teachers' written feedback practices in Hong Kong secondary classes. Journal of Second Language Writing, 17, 69-85.

Le Fevre, D. (2014). Barriers to implementing pedagogical change: The role of teachers' perceptions of risk. Teaching and Teacher Education, 38, 56-64.

Levin, B. (2010). Governments and education reform: some lessons from the last 50 years. Journal of Education Policy, 25 (6), 739-747.

Mitchell, D. (2016). Geography teachers and curriculum making in "changing times". International Research in Geographical and Environmental Education, 25 (2), 121-133. 
Mutch, C. (2012). Editorial: Curriculum change and teacher resistance. Curriculum Matters, $8,1-8$.

Nakou, I., \& Barca, I. (2010). Contemporary public debates over history education.

Charlotte, NC: Information Age Publishing.

Ormond, B. M. (2016). Curriculum Decisions - The Challenges of Teacher Autonomy over Knowledge Selection for History. Journal of Curriculum Studies, 49 (5), 599-619.

Pajares, M. F. (1992). Teachers' beliefs and educational research. Cleaning up a messy construct. Review of Educational Research, 62, 307-332.

Parsons, A., Parsons, S., Morewood, A. \& Ankrum, J. (2016). Barriers to Change: Findings from Three Literacy Professional Learning Initiatives. Literacy Research and Instruction, 55 (4), 331-352.

Priestley, M., Edwards, R., Priestley, A. \& Miller, K. (2012). Teacher Agency in Curriculum Making: Agents of Change and Spaces for Manoeuvre. Curriculum Inquiry, 42 (2), 191-214.

Robinson, S. (2012). Constructing teacher agency in response to the constraints of education policy: adoption and adaptation. The Curriculum Journal, 23 (2), 231-245.

Rogers, G. (2011). Learning-to-learn and learning-to-teach: the impact of disciplinary subject study on student-teachers' professional identity. Journal of Curriculum Studies, 43 (2), 249268.

Smith, J. (2017). Discursive dancing: traditionalism and social realism in the 2013 English history curriculum wars. British Journal of Educational Studies, 65 (3), 307-329.

Van Eekelen, I.M., Vermunt, J.D. and Boshuizen, H.P.A. (2006). Exploring teachers' will to learn. Teaching and Teacher Education, 22, 408-423.

Wilkins, C. (2011). Professionalism and the post-performative teacher: new teachers reflect on autonomy and accountability in the English school system. Professional Development in Education, 37 (3), 389-409. 
Figure 1 Overview of questions asked in each year of the survey

\begin{tabular}{|c|c|c|c|}
\hline Questions asked in the surveys relating to this study & 2015 & 2016 & 2017 \\
\hline $\begin{array}{l}\text { Variables: } \\
\text { School postcode (for IDACI data) } \\
\text { School type } \\
\text { Teacher experience } \\
\text { Teacher role in school }\end{array}$ & $\sqrt{ }$ & $\sqrt{ }$ & $\sqrt{ }$ \\
\hline $\begin{array}{l}\text { Openness to change - question about teacher reactions to the proposed changes at GCSE using a } 4 \\
\text { point scale (see Figure 2) }\end{array}$ & $\sqrt{ }$ & & \\
\hline $\begin{array}{l}\text { Are the changes at GCSE welcome - yes/no response + open ended comment about what } \\
\text { respondents were looking forward to }\end{array}$ & $\sqrt{ }$ & & \\
\hline $\begin{array}{l}\text { Are the changes at A level welcome }- \text { yes/no response + open ended comments about what } \\
\text { respondents were looking forward to }\end{array}$ & $\sqrt{ }$ & & \\
\hline Experience of change to GCSE - using 4 point scale + open ended comments & & $\sqrt{ }$ & $\sqrt{(\text { comments only) }}$ \\
\hline Experience of change to A level - using 4 point scale + open ended comments & & $\sqrt{ }$ & $\sqrt{ }$ \\
\hline $\begin{array}{l}\text { Factors influencing choice of GCSE (11 factors listed and choose as many as appropriate) (see } \\
\text { Figure 3) }\end{array}$ & $\sqrt{ }$ & & \\
\hline $\begin{array}{l}\text { Factors influencing choice of A level (10 factors listed and choose as many as appropriate) (see } \\
\text { Figure 3) }\end{array}$ & $\sqrt{ }$ & & \\
\hline The impact of changes at GCSE on the lower school curriculum - using 4 point scale & $\sqrt{ }$ & $\sqrt{ }$ & $\sqrt{ }$ \\
\hline $\begin{array}{l}\text { Different ways in which the changes at GCSE have impacted on the lower school curriculum ( } 8 \\
\text { impacts listed and choose as many as appropriate) (see Figure 4) }\end{array}$ & $\sqrt{ }$ & $\sqrt{ }$ & $\sqrt{ }$ \\
\hline
\end{tabular}


Figure 2 Question about possible ways choice of GCSE might impact on the lower school curriculum

\begin{tabular}{|c|c|c|c|c|c|c|c|}
\hline $\begin{array}{l}\text { The specific } \\
\text { content that we } \\
\text { teach - we will } \\
\text { want to avoid } \\
\text { any repetition } \\
\text { between Key } \\
\text { Stage } 3 \text { and } \\
\text { GCSE. }\end{array}$ & $\begin{array}{l}\text { The specific } \\
\text { content that we } \\
\text { teach - we will } \\
\text { plan to our } \\
\text { curriculum so } \\
\text { that we can } \\
\text { revisit some } \\
\text { aspects studied } \\
\text { at key Stage } 3 \text { in } \\
\text { more depth for } \\
\text { GCSE. }\end{array}$ & $\begin{array}{l}\text { The specific } \\
\text { content that we } \\
\text { teach - we will } \\
\text { choose content } \\
\text { carefully so that } \\
\text { Key Stage } 3 \\
\text { provides some } \\
\text { of the } \\
\text { background } \\
\text { knowledge } \\
\text { needed for } \\
\text { topics taught at } \\
\text { GCSE. }\end{array}$ & $\begin{array}{l}\text { The time-scales } \\
\text { of the topics that } \\
\text { we teach at Key } \\
\text { Stage } 3 \text { - we } \\
\text { will want to } \\
\text { give students } \\
\text { experience of } \\
\text { breadth, depth } \\
\text { and thematic } \\
\text { studies. }\end{array}$ & $\begin{array}{l}\text { The kinds of } \\
\text { questions that } \\
\text { we ask students } \\
\text { to tackle- we } \\
\text { will want to } \\
\text { reflect the style } \\
\text { and focus of any } \\
\text { new GCSE } \\
\text { questions. }\end{array}$ & $\begin{array}{l}\text { The way in } \\
\text { which we use } \\
\text { sources in Key } \\
\text { Stage } 3 \text { history. }\end{array}$ & $\begin{array}{l}\text { The way in } \\
\text { which we } \\
\text { introduce } \\
\text { students to } \\
\text { different } \\
\text { historical } \\
\text { interpretations } \\
\text { at Key Stage 3. }\end{array}$ & $\begin{array}{l}\text { The way in } \\
\text { which we tackle } \\
\text { local history or } \\
\text { the historic } \\
\text { environment at } \\
\text { Key Stage } 3 \text {. }\end{array}$ \\
\hline
\end{tabular}


Figure 3 Question about teacher reactions to the proposed changes at GCSE

\begin{tabular}{|c|c|c|c|c|c|}
\hline Change being introduced & \multicolumn{4}{|c|}{4 point Likert response scale } & Nature of the change \\
\hline $\begin{array}{l}\text { The timescale on which the changes to GCSE will have } \\
\text { to be implemented (for first examination in 2016) }\end{array}$ & \multirow{10}{*}{$\begin{array}{l}1 \\
\text { Welcome } \\
\text { the } \\
\text { change }\end{array}$} & \multirow{10}{*}{$\begin{array}{l}2 \text { No } \\
\text { concerns } \\
\text { about the } \\
\text { change }\end{array}$} & \multirow{10}{*}{$\begin{array}{l}3 \text { Some } \\
\text { concerns } \\
\text { about the } \\
\text { change }\end{array}$} & \multirow{10}{*}{$\begin{array}{l}\text { 4 Serious } \\
\text { concerns } \\
\text { about the } \\
\text { change }\end{array}$} & Practical concern \\
\hline The extent of the changes that will be involved. & & & & & Practical concern \\
\hline $\begin{array}{l}\text { The range and variety of content that students will be } \\
\text { required to study. }\end{array}$ & & & & & $\begin{array}{l}\text { Nature and value of the } \\
\text { history to be taught }\end{array}$ \\
\hline $\begin{array}{l}\text { The inclusion of subject content that I am unfamiliar with } \\
\text { or have not taught before. }\end{array}$ & & & & & $\begin{array}{l}\text { Nature and value of the } \\
\text { history to be taught }\end{array}$ \\
\hline The inclusion of a thematic study & & & & & $\begin{array}{l}\text { Nature and value of the } \\
\text { history to be taught }\end{array}$ \\
\hline The inclusion of study of the historic environment & & & & & $\begin{array}{l}\text { Nature and value of the } \\
\text { history to be taught }\end{array}$ \\
\hline $\begin{array}{l}\text { Lack of funding for the new resources that will be } \\
\text { needed. }\end{array}$ & & & & & Practical concern \\
\hline New types of exam question. & & & & & Nature of the assessment \\
\hline The use of final exams as the only method of assessment. & & & & & Nature of the assessment \\
\hline The suitability of the changes for low attainers. & & & & & Nature of the assessment \\
\hline
\end{tabular}


Figure 4 Question about factors affecting teacher choice of new examination specification

\begin{tabular}{|c|c|c|c|c|c|c|c|c|c|c|c|}
\hline & Potential fa & ors affecting & history teac & r's decisio & er new exal & lation spec & ition & & & & \\
\hline GCSE & $\begin{array}{l}\text { Prior } \\
\text { experience } \\
\text { of the exam } \\
\text { board }\end{array}$ & $\begin{array}{l}\text { Decision } \\
\text { from Senior } \\
\text { Managemen } \\
\text { t Team }\end{array}$ & $\begin{array}{l}\text { Quality of } \\
\text { support } \\
\text { materials } \\
\text { from the } \\
\text { exam board }\end{array}$ & $\begin{array}{l}\text { Minimise } \\
\text { need for } \\
\text { new } \\
\text { resources }\end{array}$ & $\begin{array}{l}\text { Teacher } \\
\text { subject } \\
\text { knowledge }\end{array}$ & $\begin{array}{l}\text { Likely } \\
\text { student } \\
\text { interest in } \\
\text { the topics } \\
\text { offered }\end{array}$ & $\begin{array}{l}\text { Style of } \\
\text { questions in } \\
\text { the new } \\
\text { examination }\end{array}$ & $\begin{array}{l}\text { The way in } \\
\text { which the } \\
\text { study of the } \\
\text { historic } \\
\text { environment } \\
\text { is tackled }\end{array}$ & $\begin{array}{l}\text { Importance } \\
\text { of topics for } \\
\text { understandi } \\
\text { ng the world } \\
\text { today }\end{array}$ & $\begin{array}{l}\text { Builds } \\
\text { on/relates to } \\
\text { KS3 } \\
\text { curriculum }\end{array}$ & $\begin{array}{l}\text { Links to the } \\
\text { A level } \\
\text { course }\end{array}$ \\
\hline A Level & $\begin{array}{l}\text { Prior } \\
\text { experience } \\
\text { of the exam } \\
\text { board }\end{array}$ & $\begin{array}{l}\text { Decision } \\
\text { from Senior } \\
\text { Managemen } \\
\text { t Team }\end{array}$ & $\begin{array}{l}\text { Quality of } \\
\text { support } \\
\text { materials } \\
\text { from the } \\
\text { exam board }\end{array}$ & $\begin{array}{l}\text { Minimise } \\
\text { need for } \\
\text { new } \\
\text { resources }\end{array}$ & $\begin{array}{l}\text { Teacher } \\
\text { subject } \\
\text { knowledge }\end{array}$ & $\begin{array}{l}\text { Likely } \\
\text { student } \\
\text { interest in } \\
\text { the topics } \\
\text { offered }\end{array}$ & $\begin{array}{l}\text { Style of } \\
\text { questions in } \\
\text { the new } \\
\text { examination }\end{array}$ & $\begin{array}{l}\text { The way in } \\
\text { which the } \\
\text { personal } \\
\text { investigatio } \\
\mathrm{n} \text { is tackled }\end{array}$ & $\begin{array}{l}\text { Importance } \\
\text { of topics for } \\
\text { understandi } \\
\text { ng the world } \\
\text { today }\end{array}$ & $\begin{array}{l}\text { Preparation } \\
\text { for } \\
\text { university } \\
\text { study }\end{array}$ & \\
\hline
\end{tabular}


Table 1 Number of responses from history teachers by school type and year of survey

\begin{tabular}{|l|l|l|l|}
\hline & 2015 & 2016 & 2017 \\
\hline Comprehensive, mixed ability & 340 & 256 & 233 \\
\hline Grammar schools & 20 & 26 & 19 \\
\hline Independent schools & 70 & 53 & 47 \\
\hline Sixth form colleges & 14 & 9 & 7 \\
\hline Unknown & 0 & 8 & 0 \\
\hline Total & 444 & 352 & 306 \\
\hline
\end{tabular}


Table 2 Mean 'openness' results

\begin{tabular}{|c|c|c|c|c|c|}
\hline & & Frequency & Percent & Valid Percent & Cumulative Percent \\
\hline \multirow[t]{24}{*}{ Valid } & 1.30 & 1 & .1 & .3 & .3 \\
\hline & 1.40 & 1 & .1 & .3 & .6 \\
\hline & 1.60 & 3 & .3 & .8 & 1.4 \\
\hline & 1.70 & 3 & .3 & .8 & 2.2 \\
\hline & 1.80 & 2 & .2 & .6 & 2.8 \\
\hline & 2.00 & 10 & .9 & 2.8 & 5.6 \\
\hline & 2.10 & 8 & .7 & 2.2 & 7.8 \\
\hline & 2.20 & 15 & 1.4 & 4.2 & 12.0 \\
\hline & 2.30 & 13 & 1.2 & 3.6 & 15.7 \\
\hline & 2.40 & 10 & .9 & 2.8 & 18.5 \\
\hline & 2.50 & 18 & 1.6 & 5.0 & 23.5 \\
\hline & 2.60 & 19 & 1.7 & 5.3 & 28.9 \\
\hline & 2.70 & 28 & 2.5 & 7.8 & 36.7 \\
\hline & 2.80 & 27 & 2.4 & 7.6 & 44.3 \\
\hline & 2.90 & 22 & 2.0 & 6.2 & 50.4 \\
\hline & 3.00 & 27 & 2.4 & 7.6 & 58.0 \\
\hline & 3.10 & 31 & 2.8 & 8.7 & 66.7 \\
\hline & 3.20 & 26 & 2.4 & 7.3 & 73.9 \\
\hline & 3.30 & 30 & 2.7 & 8.4 & 82.4 \\
\hline & 3.40 & 17 & 1.5 & 4.8 & 87.1 \\
\hline & 3.50 & 16 & 1.4 & 4.5 & 91.6 \\
\hline & 3.60 & 13 & 1.2 & 3.6 & 95.2 \\
\hline & 3.70 & 8 & .7 & 2.2 & 97.5 \\
\hline & 380 & 6 & .5 & 1.7 & 99.2 \\
\hline
\end{tabular}




\begin{tabular}{rr|r|r|r}
\hline 3.90 & 2 & .2 & .6 & 99.7 \\
\hline 4.00 & 1 & .1 & .3 & 100.0 \\
\hline Total & 357 & 32.3 & 100.0 & \\
\hline
\end{tabular}


Table 3 Experience of teaching the new A level by year of survey

\begin{tabular}{|c|c|c|c|c|c|c|c|}
\hline & & & \multicolumn{4}{|c|}{ Experience of teaching the new A level } & \multirow[b]{2}{*}{ Total } \\
\hline & & & Mainly positive & different & Very mixed & Mainly negative & \\
\hline \multirow[t]{6}{*}{ Year of survey } & 2016 & Count & 64 & 18 & 116 & 14 & 212 \\
\hline & & $\%$ within Year of survey & $30.2 \%$ & $8.5 \%$ & $54.7 \%$ & $6.6 \%$ & $100.0 \%$ \\
\hline & & $\begin{array}{l}\% \text { within Experience of teaching the new A } \\
\text { level }\end{array}$ & $45.7 \%$ & $69.2 \%$ & $54.5 \%$ & $60.9 \%$ & $52.7 \%$ \\
\hline & 2017 & Count & 76 & 8 & 97 & 9 & 190 \\
\hline & & $\%$ within Year of survey & $40.0 \%$ & $4.2 \%$ & $51.1 \%$ & $4.7 \%$ & $100.0 \%$ \\
\hline & & $\begin{array}{l}\% \text { within Experience of teaching the new A } \\
\text { level }\end{array}$ & $54.3 \%$ & $30.8 \%$ & $45.5 \%$ & $39.1 \%$ & $47.3 \%$ \\
\hline \multirow[t]{3}{*}{ Total } & & Count & 140 & 26 & 213 & 23 & 402 \\
\hline & & $\%$ within Year of survey & $34.8 \%$ & $6.5 \%$ & $53.0 \%$ & $5.7 \%$ & $100.0 \%$ \\
\hline & & $\begin{array}{l}\% \text { within Experience of teaching the new A } \\
\text { level }\end{array}$ & $100.0 \%$ & $100.0 \%$ & $100.0 \%$ & $100.0 \%$ & $100.0 \%$ \\
\hline
\end{tabular}


Table 4 Frequency count for whether teachers welcomed proposed changes to the GCSE examination

\begin{tabular}{|c|c|c|c|c|c|c|c|c|c|c|c|}
\hline & & & & & & Statistics & & & & & \\
\hline & & $\begin{array}{l}\text { Timescale for } \\
\text { implementation }\end{array}$ & $\begin{array}{l}\text { Extent of } \\
\text { changes }\end{array}$ & $\begin{array}{c}\text { Range of content } \\
\text { to be covered }\end{array}$ & $\begin{array}{c}\text { Unfamiliar } \\
\text { subject content } \\
\end{array}$ & Thematic study & $\begin{array}{c}\text { Inclusion of } \\
\text { historic } \\
\text { environment }\end{array}$ & Lack of funding & $\begin{array}{c}\text { New style } \\
\text { GCSE }\end{array}$ & $\begin{array}{c}\text { Use of } \\
\text { summative } \\
\text { assessment only } \\
\end{array}$ & $\begin{array}{c}\text { Appropriateness } \\
\text { for lower } \\
\text { attainers } \\
\end{array}$ \\
\hline $\mathrm{N}$ & Valid & 370 & 370 & 368 & 365 & 368 & 367 & 367 & 369 & 367 & 370 \\
\hline & Missing & 734 & 734 & 736 & 739 & 736 & 737 & 737 & 735 & 737 & 734 \\
\hline Mean & & 3.12 & 3.19 & 2.88 & 2.64 & 2.22 & 2.56 & 3.51 & 2.76 & 2.74 & 3.32 \\
\hline Median & & 3.00 & 3.00 & 3.00 & 3.00 & 2.00 & 3.00 & 4.00 & 3.00 & 3.00 & 3.00 \\
\hline Mode & & 3 & 3 & 3 & $2^{\mathrm{a}}$ & 2 & 3 & 4 & 3 & 3 & 4 \\
\hline Std. Dey & & .770 & .736 & .990 & .828 & .796 & .837 & .673 & .762 & 1.043 & .777 \\
\hline
\end{tabular}

a. Multiple modes exist. The smallest value is shown 
Table 5 Teachers' experience of change

\begin{tabular}{|l|l|l|l|l|}
\hline \multirow{2}{*}{} & 2016 & A level & GCSE & A level \\
\cline { 2 - 5 } & GCSE & 6 & 8 & 9 \\
\hline $\begin{array}{l}\text { Number of positive } \\
\text { comments }\end{array}$ & 31 & 17 & 72 & 27 \\
\hline $\begin{array}{l}\text { Number of } \\
\text { negative comments }\end{array}$ & 57 & 23 & 80 & 36 \\
\hline $\begin{array}{l}\text { Total number of } \\
\text { comments }\end{array}$ & 88 & & & \\
\hline
\end{tabular}


Table 6 Factors that influenced teachers' choice of exam courses

\begin{tabular}{|l|c|c|l|c|c|}
\hline GCSE & $\begin{array}{l}\text { Number of } \\
\text { responses }\end{array}$ & Percentage & A level & $\begin{array}{l}\text { Number of } \\
\text { responses }\end{array}$ & Percentage \\
\hline $\begin{array}{l}\text { Prior experience of the } \\
\text { exam board }\end{array}$ & 316 & $74 \%$ & $\begin{array}{l}\text { Prior experience of the } \\
\text { exam board }\end{array}$ & 228 & $76 \%$ \\
\hline $\begin{array}{l}\text { Likely student interest in the } \\
\text { topics offered }\end{array}$ & 266 & $62 \%$ & Teacher subject knowledge & 222 & $74 \%$ \\
\hline $\begin{array}{l}\text { Minimise need for new } \\
\text { resources }\end{array}$ & 254 & $59 \%$ & $\begin{array}{l}\text { Likely student interest in } \\
\text { the topics offered }\end{array}$ & 201 & $67 \%$ \\
\hline $\begin{array}{l}\text { Quality of support materials } \\
\text { from the exam board }\end{array}$ & 252 & $59 \%$ & $\begin{array}{l}\text { Quality of support } \\
\text { materials from the exam } \\
\text { board }\end{array}$ & 167 & $56 \%$ \\
\hline $\begin{array}{l}\text { Teacher subject knowledge } \\
\text { Styimise need for new } \\
\text { resources }\end{array}$ & 236 & $55 \%$ & 151 & $50 \%$ \\
\hline $\begin{array}{l}\text { Sinks of questions in the } \\
\text { new examination level course }\end{array}$ & 198 & $46 \%$ & $\begin{array}{l}\text { tryle of questions in the } \\
\text { new examination }\end{array}$ & 110 & $37 \%$ \\
\hline $\begin{array}{l}\text { Builds on/relates to KS3 } \\
\text { curriculum }\end{array}$ & 107 & $25 \%$ & $\begin{array}{l}\text { The way in which the } \\
\text { tersonal investigation is } \\
\text { tackled } \\
\text { study }\end{array}$ & 63 & $21 \%$ \\
\hline $\begin{array}{l}\text { Importance of topics for } \\
\text { understanding the world } \\
\text { today }\end{array}$ & 101 & $24 \%$ & $\begin{array}{l}\text { Importance of topics for } \\
\text { understanding the world } \\
\text { today }\end{array}$ & 53 & $18 \%$ \\
\hline $\begin{array}{l}\text { The way in which the } \\
\text { historic environment is } \\
\text { tackled }\end{array}$ & 95 & $22 \%$ & $\begin{array}{l}\text { Decision from Senior } \\
\text { Management Team }\end{array}$ & 16 & $5 \%$ \\
\hline $\begin{array}{l}\text { Decision from Senior } \\
\text { Management Team }\end{array}$ & 25 & $6 \%$ & & 59 & $5 \%$ \\
\hline
\end{tabular}

